\begin{tabular}{|c|c|c|}
\hline $\begin{array}{l}\text { KULTURA } \\
\text { I } \\
\text { SPOLECZENS }\end{array}$ & $\begin{array}{l}\text { POLSKA AKADEMIA NAUK } \\
\text { KOMITET SOCJOLOGII } \\
\text { INSTYTUT STUDIÓW POLITYCZNYCH } \\
2015, \mathrm{nr} 4\end{array}$ & ISSN 0023-5172 \\
\hline
\end{tabular}

JOLANTA GŁADYS-JAKÓBIK

Szkoła Główna Handlowa

BARBARA POST

Szkoła Gtówna Gospodarstwa Wiejskiego

\title{
WZORY SUKCESU \\ W NARRACJACH ELIT ADMINISTRACYJNYCH PAŃSTWA
}

Autorzy zajmujący się problematyką administracji zwracają uwagę, że $\mathrm{w}$ prowadzonych do tej pory badaniach dominują koncepcje wywodzące się $z$ teorii racjonalnego wyboru oraz nurtu neoinstytucjonalnego (Hensel, Glinka 2012, s. 28). Te pierwsze koncentrują się na pokazywaniu, w jaki sposób zachowania pojedynczych urzędników są determinowane przez otaczające ich układy zachęt i interesów, natomiast $\mathrm{w}$ nurcie neoinstytucjonalnym podkreśla się znaczenie zastanych instytucji, służących jako narzędzia interpretacji rzeczywistości (March, Olsen 2005). Przemysław Hensel i Beata Glinka wyróżniają trzy paradygmaty postrzegania i reformowania administracji na przełomie XX i XXI wieku: hierarchiczny, rynkowy i sieciowy. Każdy z nich obejmuje nie tylko zestaw technicznych wskazówek pokazujących dobre praktyki czy cele możliwe do osiągnięcia, ale co istotne, umożliwia także zrozumienie otaczającej rzeczywistości i nadanie jej sensu. Przywołani autorzy przyjmują za Bergerem i Luckmanem, że rzeczywistość jest konstruowana społecznie, a podstawowe znaczenie dla podejmowanych decyzji mają intersubiektywne interpretacje rzeczywistości, której odbiór wynika z obowiązującego w danym okresie paradygmatu.

Ilustracją może być zmiana systemu politycznego w Polsce po 1989 roku — nieoczekiwana i nie poprzedzona wcześniejszym przygotowaniem intelektualnym. Można zatem oczekiwać, że adaptacja do nowych warunków doprowadzi do skonstruowania nowej formy paradygmatu, w której cześć zasad zostanie odrzucona, część źle zrozumiana lub przyjęta powierzchownie, często jednak 
przy publicznej deklaracji ich akceptacji. Autorzy przywoływanej pracy zwracają uwagę, że polska administracja funkcjonuje w czasach ideologicznego zamętu, wynikającego nie tylko ze zmian systemowych zapoczątkowanych w 1989 roku, ale także $z$ przekształceń paradygmatów dotychczas obserwowanych $\mathrm{w}$ państwach rozwiniętych. Polscy urzędnicy po latach obowiązywania paradygmatu biurokratycznego, znaleźli się w kolejnym — rynkowym, by ponownie zmieniać swój sposób myślenia - na charakterystyczny dla paradygmatu sieciowego. W konsekwencji tej sytuacji, jak piszą Hensel i Glinka (2012, s. 34), można „podejrzewać, że tak szybko następujące po sobie zmiany «niepodważalnych prawd», mogą powodować cyniczny stosunek urzędników do wszelkich pomysłów reformatorskich". Nie przesądzając o trafności lub nietrafności powyższej refleksji, można postawić tezę, że reformy ostatnich dwudziestu pięciu lat oraz immanentne cechy modelu biurokratycznego definiują współcześnie role zawodowe i tożsamość urzędników administracji państwowej w Polsce.

Rolę można zdefiniować jako miejsce zajmowane przez jednostkę w systemie, do którego przypisany jest określony zbiór skryptów postępowania. Każdy aktor może go po swojemu interpretować, ucząc się na własnych błędach tego, co jest i co nie jest akceptowane. Pojęcie tożsamości zaś oznacza autodefinicję konkretnego aktora w systemie. Zbigniew Bokszański (1990, s. 83) pisał: „Tożsamość aktora społecznego pojmować można [...] jako zbiór wyobrażeń, sądów i przekonań, które konstruuje on wobec samego siebie. Ujmując rzecz jeszcze lapidarniej, tożsamość to układ autodefinicji aktora społecznego". Tak rozumiany proces definiowania przebiega zawsze $\mathrm{w}$ określonym kontekście społecznym, a jego ważny element stanowi „przeglądanie się w oczach innych". Zatem to akceptacja ze strony innych stanowi warunek prawidłowego postrzegania samego siebie, prowadząc do zachowań konformistycznych, czyli bycia „wbudowanym w system”. Procesy uczenia się nowych ról mają więc określone konsekwencje zarówno dla tożsamości uczestników badania, którego wyniki dalej analizujemy, jak i tego, w jaki sposób próbują się prezentować w wywiadach ${ }^{1}$.

Warto podkreślić, że zarówno odgrywane role, jak i sposoby definiowania tożsamości mają znaczenie dla jakości funkcjonowania administracji. March i Olsen zakładali, że w swoich wyborach ludzie nie kierują się jedynie racjonalną kalkulacją zysków i strat, ale także wartościami i normami związanymi z sytuacją i pełnioną rolą społeczną. Tak rozumiany proces podejmowania decyzji składa się $z$ trzech sekwencji. W pierwszej pojawia się pytanie „W jakiej sytuacji się znajduję?”, w drugiej „kim jestem?”, trzecia natomiast zawiera próbę udzielenia odpowiedzi na pytanie: „jak w danej sytuacji powinienem się zachować?". Definicje pełnionej roli społecznej i związanych z nią warto-

${ }^{1}$ Materiał empiryczny poddany dalej analizie został zebrany w 2013 roku w trakcie realizacji jakościowej części badania prowadzonego w ramach grantu NCN pt. „Elity administracyjne i polityczne państwa: kariery tożsamości, relacje” (nr 2011/03/B/HS5/00825). 
ści okazują się zatem istotne dla zrozumienia zasad, na których opierają się $\mathrm{w}$ działaniu polskie elity administracyjne.

Jednym $z$ wymiarów tak rozumianej tożsamości jest sposób, w jaki dyrektorzy i wicedyrektorzy pięćdziesięciu departamentów, wylosowanych ze zbioru departamentów merytorycznych niemal wszystkich resortów, definiują pojęcie sukcesu zawodowego. Jakościowa analiza zgromadzonych wypowiedzi pozwala w tym wypadku, po pierwsze, nie tylko na przestawienie ich perspektywy, ale również na próbę odpowiedzi na pytanie o spójność wzorów myślenia rządowych elit administracyjnych w odniesieniu do interesującej nas kwestii. Po drugie - na ewentualne przedstawienie sposobów, $\mathrm{w}$ jakie rozumienie tego pojęcia wpływa na pełnione role zawodowe. Po trzecie wreszcie, interesowało nas także to, w jakim tonie toczyły się analizowane narracje: przybierały postać proaktywną, defensywną czy być może jakąś inną (Trzebiński 2002).

Zobaczmy zatem, jak przedstawiciele elity administracyjnej postrzegają swoje role, odwołując się do wymiaru, jakim jest sukces, niejako „z definicji" przynależny do paradygmatu gospodarki rynkowej i związanej z nim ideologii, która oprócz nastawienia na sukces materialny kładzie także nacisk na związany z nim indywidualizm, optymizm, pozytywne myślenie, samorealizację oraz nastawienie konsumpcyjne (Grzeszczyk 2003). Część badaczy, pisząc o imitacyjnym charakterze polskich przemian, zwraca uwagę, że zachodnie wzory nie rozpowszechniają się u nas bez przeszkód. Sukces (zwłaszcza w wymiarze materialno-zawodowym) jest bowiem różnie postrzegany w różnych środowiskach. Można to interpretować odwołując się między innymi do tego, w jaki sposób przedstawiciele elity administracyjnej definiują swoje miejsce i rolę w nowej rzeczywistości. Co oznacza zatem dla nich sukces i jakie ma to konsekwencje dla kształtowania nowych tożsamości?

\section{WYMIARY ADMINISTRACYJNEGO SUKCESU}

Jeżeli wstępnie przyjmiemy najprostszą, słownikową definicję sukcesu, zgodnie z którą sukces to „spełnione zamierzenie, pomyślny wynik jakiegoś przedsięwzięcia”, możemy powiedzieć, że te „spełnione zamierzenia”, czyli „przekonanie, że nam się powiodło, że osiągnęliśmy jakiś cel, uzyskaliśmy to, na czym nam zależało" (Sikorski 2007, s. 11), są lokowane przez naszych rozmówców w kilku wymiarach. Sukces ma postać relacyjną oraz jest różnie postrzegany w zależności od założonych celów, którymi - jak wynika z narracji dyrektorów departamentów polskich ministerstw - są po pierwsze, realizowane przez ich zespoły zadania, po drugie - ich własny sukces zawodowy i wynikająca $z$ niego satysfakcja oraz po trzecie - pozytywne, zewnętrzne oceny wykonywanej przez nich pracy.

Tego typu wypowiedzi rejestrowaliśmy najczęściej, warto jednak dodać, że są one wewnętrznie zróżnicowane i nie wyczerpują wszystkich sformułowanych przez respondentów charakterystyk sukcesu „w administracji”. Między 
innymi $z$ tego powodu, analizując interesującą nas kwestię, dalej będziemy używać zwrotu „wymiary sukcesu”. Chcemy w ten sposób podkreślić, że owym sukcesom — również wtedy, gdy są podobnie rozumiane - mogą towarzyszyć różne miary. Należy też dodać, że relacje większości dyrektorów najczęściej są organizowane w sposób wskazujący na to, że lokują oni sukces w ramach jednego ze wskazanych wyżej trzech ogólnych wymiarów. Rzadziej pojawiają się wypowiedzi, których autorzy opisują sukces w kontekście różnych celów, najrzadziej natomiast takie, które świadczą o tym, że w odniesieniu do urzędniczej profesji mówienie o sukcesie to jest dość względna i dyskusyjna kwestia [R. 10]2. Na czym więc, zdaniem naszych rozmówców, polega bądź może polegać sukces w takiej pracy, jak ta, którą sami wykonują?

Jak się okazuje, przede wszystkim na tym, aby sprawnie i efektywnie - czyli szybko i adekwatnie - realizować założone cele i wynikające $z$ nich zadania ${ }^{3}$. Ze względu na ich różnorodność ten wymiar administracyjnego sukcesu mieści się, jak można powiedzieć, na szerokim kontinuum obejmującym zarówno rozstrzygnięcia konkretnej sprawy, jak i przenoszenie do Polski dobrych rozwiazan z Unii Europejskiej. Sukcesem, zgodnie z tym sposobem jego rozumienia, są więc $z a-$ kończone projekty, przygotowane akty prawne, wydane decyzje [R. 30]; projekty rozporządzeń przeprowadzone przez wszystkie szczeble uzgodnień [R. 22]; przyjęcie ustawy [...], prawidtowe $i$ terminowe prowadzenie postępowan administracyjnych [R. 23] bądź przeforsowanie jakiegoś aktu prawnego czy wydanie jakiś wytycznych, które sie sprawdzaja [...] przekonanie instytucji zarządzającej do jakiegoś rozwiązania [R. 40]. Sukcesem okazuje się zarówno powstanie nowej struktury [R. 2], jak i sprawne zarzadzanie struktura [R. 17] już istniejąca, ale także o sukcesie decyduje jakość przedstawianych materiatów $i$ analiz [R. 18]; konferencje, posiedzenia [R. 22] czy podpisanie umowy jednej, drugiej; doprowadzenie do wizyty, spotkania [R. 25]. Sukces wreszcie to także dobrze wydane środki [R. 28], wdrażanie nowych rozwiazań [R. 15] czy - dobrze przedstawione stanowisko Polski na forum UE [R. 34].

Powyższe i pozostałe $z$ zaliczonych do tej grupy deskrypcje sukcesu można w jej ramach podzielić, odwołując się do różnych kryteriów. Pierwszym może być waga realizowanego bądź zrealizowanego zadania - może być ono „małe” (jakaś istotna konferencja, posiedzenie - R. 22) lub „duże” (przejście przez proces legislacyjny - R. 47). Drugim kryterium jest to, czy dany cel został już zrealizowany (osiagnięcie jakiegoś etapu, czyli zamknięcie programu - R. 44), czy też dopiero jest wypracowywany lub trwa proces jego realizacji (przygotowywanie nowych rozwiązań - R. 10; realizacja celów i projektów, ich potwierdzanie w działaniu - R. 20). Kolejne kryterium pozwala podzielić wskazania naszych rozmówców na sukcesy „wewnętrzne”, takie jak to, że udało się stworzyć ten zespót, który jest

\footnotetext{
2 Przywoływane w tekście fragmenty wywiadów wyróżnione są kursywą i sygnowane numerem nadanym danemu wywiadowi.

3 Do tej grupy zostało zaliczonych 28 wypowiedzi, zawierających łącznie 40 egzemplifikacji tak rozumianego sukcesu.
} 
sprawnym narzędziem $w$ ręku ministra [R. 16] lub to, że nie odstajemy od takich kompetencji rynkowych [R. 12], oraz „zewnętrzne”, których miarą jest na przykład to, że nie straciliśmy środków [...], że udało się wiele podmiotów zmusić do dialogu [R. 44]. Kryteria te występują $\mathrm{w}$ różnych konfiguracjach lub rozłącznie, można także dodać, że zawarte $\mathrm{w}$ powyższych wypowiedziach charakterystyki sukcesu mają albo charakter szczegółowy, albo bardziej ogólny.

Niezależnie jednak od przyjętej formy i stylu wypowiedzi — w których najczęściej pojawiają się takie zwroty, jak „sprawy”, „decyzje”, „projekty”, „programy”, , akty prawne” czy „proces legislacyjny” - nietrudno zauważyć, analizując te najczęściej wskazywane i opisywane egzemplifikacje administracyjnego sukcesu, że wiążą się one z zadaniami, które powinna realizować administracja publiczna. W jednej z prac prezentujących nowe podejścia do zadań administracji można znaleźć następującą konstatację: „Administracja publiczna powinna dostarczać - w sposób sprawny i przejrzysty — dobra i usługi publiczne oraz zapewniać odpowiednie warunki dla działalności gospodarczej. Systemy administracji publicznej powinny być otwarte, demokratyczne, skuteczne i wydajne" (Płoskonka 2008, s. 171). Nie sposób przesądzić o tym, czy uczestnicy naszego badania poparliby ideę zarządzania przez rezultaty jako najlepszą metodę wykonywania zadań przez administrację publiczną. Możemy jednak powiedzieć, $\dot{z}$ e wydaje się, iż ponad połowa $z$ nich, opisując sukces $\mathrm{w}$ administracji, lokuje go właśnie w tym kontekście.

Drugi sposób rozumienia tego, czym jest (lub może być) sukces w administracji publicznej, ma już inny charakter. Jest on ujmowany wyłącznie lub przede wszystkim w wymiarze osobistym, indywidualnym. „Z faktu, że sukces niejedno ma imię i przejawiać się może w nieskończonej palecie odczuć i wyobrażeń — zauważa Czesław Sikorski (2007, s. 14) — nie wynika jednak brak wspólnych cech, które mogłyby posłużyć do kategoryzacji rodzajów sukcesu". Otóż wspólną cechą wypowiedzi tworzących tę grupę ${ }^{4}$ jest to, że ich autorzy mówiąc o sukcesie, opisują de facto własny sukces zawodowy. Jego miarą pozostają "spełnione zamierzenia" - nie egzemplifikują ich już cele i zadania stojące przed administracją publiczną jako instytucją, lecz przede wszystkim cele organizujące indywidualne kariery.

Także te deskrypcje można ująć w pewne kontinuum, które otwiera - sukces to „utrzymanie stanowiska”, a zamyka — sukces to również „zadowolenie $z$ tego, co się robi". Ten personalny wymiar sukcesu odniesionego w strukturach administracji publicznej bywa akcentowany za pomocą zwrotów typu: jeśli chodzi o mnie osobiście... [R. 10], mój sukces polega na... [R. 33] czy moim sukcesem jest... [R. 24]. Tak czy inaczej tak rozumiany sukces, bardzo minimalistycznie definiowany - jak mówił jeden z naszych rozmówców — polega na tym, że bez przerwy się czlowiek na tym stanowisku utrzymuje $i$ to, co robi, nie wzbudza watpli-

\footnotetext{
${ }^{4}$ Obejmuje ona czternaście wypowiedzi.
} 
wości [R. 19]. W wersji „rozszerzonej” definicja taka przyjmuje następującą postać: Sukcesem jest na pewno to, że pracuje tu od czternastu lat. Sukces ten polega nie tylko na tym, że nikt mnie wyrzucit w tym czasie, tylko że mimo różnych wad tej pracy, nie przyszło mi do głowy, żeby ja zmienić [R. 29].

Własna kariera czy własny sukces zawodowy [R. 2] są więc w tym wypadku, naturalnym skądinąd, powodem do zadowolenia i satysfakcji. Emocje te, jak wynika z wypowiedzi części badanych, nie są jednak wyłącznie konsekwencją skutecznego realizowania założonych celów przez tych, którzy do tak definiowanego sukcesu dążyli bądź dążą. „Mój sukces” i towarzysząca mu satysfakcja wiążą się także z tym, jak mówili niektórzy, [...] że sobie potrafitem przez te lata dosyć tak bezkolizyjnie i sprawnie poradzić z organizowaniem kolejnych komórek, którymi później przyszło mi kierować [R. 10]; [...] że nie ma takich spraw, które bym kiedyś załatwiat $w$ przeszłości, co do których miałbym poczucie, że je źle załatwitem [R. 4]. Innymi słowy mówiąc, sukcesowi lokowanemu $\mathrm{w}$ wymiarze personalnym $\mathrm{z}$ reguły towarzyszy zadowolenie $z$ tego, co się robi; poczucie, że się to robi dobrze [R. 13] - a kolejnym tego wyrazem, dobrze widocznym w naszym materiale, wydaje się następująca wypowiedź: moim sukcesem jest również zespót, który pracuje efektywnie, ciężko i jest zadowolony z efektów wspótpracy [R. 41].

Miarą kolejnego, trzeciego sposobu rozumienia sukcesu okazują się relacje z otoczeniem - zarówno tym najbliższym (departament, ministerstwo), jak i z podmiotami zewnętrznymi, z którymi nasi rozmówcy kooperują ${ }^{5}$. Na ogół nie mówią oni jednak w tym wypadku o satysfakcjonującej lub mniej udanej współpracy czy wspólnie zrealizowanych celach, ale o tym, jak ich praca jest lub bywa oceniana. Pierwsza myśl, która mi przychodzi [do głowy] — wskazuje więc jeden $z$ badanych - to jest to pozytywny odbiór z zewnatrz. Znaczy to, że nie tylko przetożeni, ale też całe środowisko, $w$ którym pracuje, generalnie pozytywnie oceniaja, doceniaja $w$ dtuższej perspektywie czasowej działania, ich charakter, sposób. Wysoka ocena z zewnattrz. Być może idzie za tym $i$ jakiś prestiż [R. 11]. Z innej wypowiedzi egzemplifikującej ten wymiar administracyjnego sukcesu dowiadujemy się, po pierwsze, że ów „pozytywny odbiór z zewnątrz” stanowi nie tylko istotny warunek sukcesu — ale także powód do satysfakcji i dumy. Jest to opisywane tak: Ale sukcesem dla mnie jest, wie pani co, kiedy zbieramy opinie pozytywne. To jest może nie sam sukces, ale pewna miara tego urzędniczego sukcesu, czyli jak gdyby stwierdzenia, że nasza praca jest wtaściwa, jest potrzebna, że jest oceniana pozytywnie. A musze powiedzieć, że ostatnio coraz częściej te pozytywne opinie styszę, to jest takie budujące [R. 32].

Warto może jednak dodać, że taka sytuacja - czyli pozytywne informacje zwrotne na temat wykonywanej pracy oraz wynikająca $z$ tego satysfakcja — niekoniecznie jest udziałem autorów wszystkich wypowiedzi tworzących tę grupę. Jak wynika $z$ narracji, w tym wypadku miarą sukcesu bywa zarówno brak negatywnych uwag [...], jak i to, jak czlowiek jest postrzegany przez innych

${ }^{5}$ Do tej grupy zostało zaliczonych dwanaście wypowiedzi. 
— jeżeli jesteśmy wyróżniani w jakiś sposób przez zewnętrzne organizacje czy przez inne resorty $z$ którymi wspótpracujemy [R. 13]. Uznanie ze strony zewnętrznych interesariuszy, jak podkreśla dalej ten sam rozmówca, nie oznacza jednak, że automatycznie należy spodziewać się tego samego we własnym ministerstwie: natomiast $w$ wewnętrznych relacjach, no to czasami nas chwala szefowie nasi, ale to nie jest jakieś zjawisko powszechne raczej. Tymczasem jest to istotne, jak się okazuje, $z$ punktu widzenia pozycji zawodowej oraz własnej kariery. W następujący sposób mówi o tym jeden $\mathrm{z}$ dyrektorów: Na pewno sukcesem jest jakaś pozycja osobista, to znaczy - jak jest sie postrzeganym $w$ środowiskach, $z$ którymi sie pracuje, czy ta zewnętrzna - też jak jest sie postrzeganym $w$ ministerstwie [R. 6]. Inny stwierdza ogólnie, że trzeba, po pierwsze, być jakoś zauważonym, i wyjaśnia dalej, że jest to istotne, ponieważ: Jak sie jest docenionym, to się wtedy awansuje, ale to różnie bywa, bo sa przypadki, że ludzie sa niedocenieni, bo wszyscy nie moga awansować [R. 3].

Można powiedzieć, abstrahując od stylistyki oraz formy poszczególnych wypowiedzi egzemplifikujących tak charakteryzowany sukces, że ich autorzy, niezależnie od tego, czy utożsamiają sukces z pozytywna opinia wśród przetożonych [R. 13], czy wskazują na to, że jego miarą jest to, jak się jest postrzeganym $w$ środowiskach, $z$ którymi sie pracuje [R. 6], są przekonani o tym, że jest on wypadkową ocen zewnętrznych.

Trzy powyższe, wewnętrznie zróżnicowane sposoby definiowania sukcesu, do których najczęściej odwoływali się badani dyrektorzy, zostały przez nas określone jako wymiar zadań, wymiar własnej kariery i wymiar zewnętrznych ocen. Nie obejmują one jednak tych narracji, których autorzy wydają się przekonani, że odpowiedź na pytania dotyczące tego, czym jest sukces w pracy, jaką wykonują, oraz co może być jego miarą, jest po pierwsze dyskusyjna, a po drugie - trudna. Właśnie tego typu wypowiedzi składają się na ostatnią, czwartą grupę prezentowanej typologii ${ }^{6}$. Należy podkreślić, że tu także znajdujemy przykłady świadczące o tym, czym jest lub może być sukces „W administracji”, wpisujące się w przedstawione wyżej wymiary. Cechą wspólną tych narracji było jednak to, że rozpoczynały je refleksje typu: To zależy od tego, jak definiujemy sukces $w$ tej pracy [R. 15]; Trudno sukces mierzyć [R. 30]; Sukces? Tu bardzo ciężko mówić o sukcesie [R. 25]; O sukces $w$ pracy administracji jest bardzo trudno [R. 6] bądź na przykład: Nie wiem. To znaczy ... różnie [R. 5]. Innymi słowy, ten sposób rozumienia interesującej nas kwestii (i tę grupę wypowiedzi) różni od przedstawionych wyżej nie to, że brak tu takich czy innych wskazań, ale to, że pojawiały się one niejako w drugiej kolejności. Przede wszystkim mówiono o tym, że odpowiedź na pytanie dotyczące tego, na czym polega sukces w pracy urzędnika administracyjnej publicznej: To jest dosyć względna $i$ dyskusyjna kwestia [R. 10].

${ }^{6}$ Obejmuje ona osiem deskrypcji. 
Po pierwsze dlatego, że odpowiedź ta zależy od przyjętych definicji sukcesu, ponieważ $\mathrm{w}$ konsekwencji na przykład można bardzo minimalistycznie definiować, przez to, że sie człowiek na tym stanowisku utrzymuje $i$ to, co robi, nie wzbudza watpliwości [...]. Mnie sie jednak wydaje — stwierdza dalej ten sam rozmówca - że sukces to zrobienie czegoś pożytecznego, nie tylko dla swojej wtasnej organizacji, ale też dla szerszej rzeszy odbiorców [R. 15]. Inny, zwracając uwagę na to, że miarą sukcesu jest jego relacja do zamierzeń, podkreśla: Zeby mówić o sukcesie, musimy mówić o pewnych celach, które mamy zatożone $i$ wtedy, kiedy te cele osiagamy, to możemy mówić o sukcesie [...] [R. 41]. Cechą łączącą powyższe deskrypcje jest zwrócenie uwagi na to, że w praktyce funkcjonowania administracji publicznej sukces jest trudno zmierzyć. Mamy tu oczywiście sprawozdawczość [R. 30] — mówią badani, ale jednocześnie podkreślają i to, że są rzeczy, które można kwalifikować i sa niekwalifikowane rzeczy [...] oczywiście, że różnych działan dotyczy, tu nie ma dziatań powtarzalnych [R. 26] Sukcesem mogą więc być zarówno jednostkowe „sprawy” (np. różne drobniejsze rzeczy, o których się nie styszy - R. 40), jak i to, że wszystko idzie do przodu, że mimo jakichś utrudnień na tyle na ile potrafimy, na ile jesteśmy $w$ stanie, realizujemy te zadania [R. 25] bądź przychodzące $z$ czasem przekonanie, że efekty podejmowanych działań służą społeczeństwu ${ }^{7}$.

Powyższe refleksje pokazują, że sukces w administracji — jak to ujął autor jednej z należących do tej grupy narracji - Na pewno jest wielowymiarowy, nie da się go jednoznacznie zdefiniować. On ma kilka różnych aspektów, może być to sukces finansowy albo spoteczny, osobisty - taki dotyczacy wtasnej wartości czy wtasnego wyobrażenia o sobie [R. 11]. Wyniki przedstawionej analizy świadczą jednak o tym, że zdecydowana większość dyrektorów departamentów definiuje ów sukces w konkretny sposób, najczęściej w kontekście realizowanych zadań, następnie własnej kariery lub zewnętrznych pozytywnych ocen. Warto także zauważyć, że tylko raz zarejestrowałyśmy wypowiedź świadczącą o tym, że osiągnięcie sukcesu - a raczej znaczącego „jednego sukcesu”, jak mówi jej autor — jest w administracji publicznej w zasadzie niemożliwe. Brzmi ona tak: Tu nie ma sukcesu. Sukcesem jest może to, że kolejny konkret, pozytywnie zakończone sensowne rzeczy sa sukcesami - ale nie ma czegoś takiego jak jeden sukces, bo jest pani ograniczona tym, że zaraz moga pania odwołać [R. 7]. Także tylko w jednej ze zgromadzonych narracji znajduje się diagnoza przyczyn, dla których „o sukces w pracy administracyjnej jest bardzo trudno" [R. 6]. Otóż: po pierwsze dlatego, $\dot{z}$ e administracja nie ma takich wyraźnych punktów zwieńczeń. Te punkty zwieńczenia przebiegaja w sferze politycznej: podsumowuje się jakaś kadencję, ale to jednak zawsze jest czynnik zewnętrzny. [...] Praca administracyjna jednak polega na pewnej takiej

\footnotetext{
${ }^{7} \mathrm{~W}$ tym wypadku rozmówca na pytanie o sukces najpierw zareagował odpowiedzią „nie wiem”, a następnie wyjaśniał: [...] myśle, że to bytoby złe, gdybym miat na celu jakiś sukces. Ale moim zdaniem to, co się robi - jeżeli po pewnym czasie społeczeństwu stuży i traktuje to jako oczywista oczywistość - to jest sukces. Natomiast to nie jest robione, żebym ja miat $z$ tego [...] [R. 27].
} 
ciagłości, takim swoistym perpetuum mobile, to się nigdy nie kończy, nigdy nie można powiedzieć, że wtaśnie się odniosto sukces [R. 6].

\section{KORELATY SUKCESU ADMINISTRACYJNEGO}

Można jednak - zdaniem naszych rozmówców - wskazać okoliczności sprzyjające osiągnięciu sukcesu zawodowego w administracji. Otóż niezależnie od tego, jak był on rozumiany i definiowany, badani dyrektorzy wskazują przede wszystkim na związek między ewentualnym sukcesem a cechami osobistymi i umiejętnościami urzędników ${ }^{8}$. Mówiąc o tym, że na pewno jest wiele cech wśród ludzi, które pomagaja osiagnać sukces [R. 32], koncentrowali się jednak na takich cechach, które dotyczą wiedzy i kompetencji oraz doświadczenia zawodowego. Podkreślali przede wszystkim, że: Trzeba być merytorycznie bardzo dobrym [R. 18], dodając, że sukcesowi sprzyjają analityczny umyst [R. 15], umiejętność analizowania i wyciagania wniosków [R. 8], otwarta głowa [R. 44] oraz szeroko rozumiane kompetencje. Kompetencje, na które - jak mówili - wiele rzeczy się składa: poczawwszy od wykształcenia, doświadczenia zawodowego do pewnych predylekcji osobistych [R. 6].

Drugą wyraźnie zaznaczającą się grupą cech wiążących się z sukcesem okazały się umiejętności komunikacyjne. Nasi rozmówcy wskazywali w tym wypadku między innymi na umiejętność kreowania dobrych kontaktów międzyludzkich [R. 2], łatwość nawiązywania kontaktów z otoczeniem [R. 17] czy koncyliacyjność [R. 21]. Wszystkie te cechy, ich zdaniem, zwiększają prawdopodobieństwo odniesienia sukcesu oraz szanse na taką współpracę $z$ wewnętrznymi oraz zewnętrznymi intersariuszami, w którą wpisana jest: Elastyczność $w$ sensie szukania porozumienia, umiejętność stuchania argumentów [...] korzystanie $z$ wiedzy ekspertów, umiejętność negocjacji [R. 39].

Powyższe wskazania w gruncie rzeczy nie ułatwiają odpowiedzi na pytanie o to, czy w środowisku badanych istnieje wzór sukcesu, naznaczony profesjonalną charakterystyką oraz wrażliwością na spełnianie standardów środowiskowych „fachowej roboty”. Problem polega na tym, że - jak wynika z przedstawionej analizy - mamy do czynienia nie tyle z jednym dominującym wzorem ile $z$ co najmniej trzema, wewnętrznie zróżnicowanymi sposobami rozumienia i postrzegania tej kwestii. Jednak biorąc pod uwagę wskazywane w analizowanych narracjach korelaty sukcesu „W administracji”, można zaryzykować tezę, że choć różnie definiowany, wiąże się on $z$ atrybutami charakterystycznymi dla procesów profesjonalizacji roli zawodowej urzędnika.

\footnotetext{
8 Stworzona na podstawie tych wskazań typologia obejmuje pięć grup cech. Dwie najliczniejsze dotyczą wiedzy i kompetencji merytorycznych oraz kompetencji komunikacyjnych. Do kolejnych trzech grup zostały zaliczone cechy wskazywane z niemal taką samą częstotliwością, choć rzadziej. Koncentrują sie one wokół inicjatywy i kreatywności (grupa trzecia), zaangażowania i wiary w sens podejmowanych działań (grupa czwarta) oraz rzetelności i pracowitości (grupa piąta).
} 
W słownikowych definicjach termin „profesja” odnosi się do tych zawodów, których wykonywanie wymaga wyspecjalizowanej wiedzy i umiejętności. Autorzy socjologicznych prac poświęconych zawodom typu professions, definiując przedmiot swoich zainteresowań, na ogół wymieniają cechy i wymogi, jakim powinni sprostać ci, którzy zawody te wykonują - wskazując także, często na pierwszym miejscu, na konieczność posiadania uogólnionej wiedzy (Barber 1963; Harries-Jenkins 1970).

W naukach o zarządzaniu z kolei pojęcie profesjonalizmu bywa współcześnie analizowane w dwóch powiązanych perspektywach (Kafel 2013). Pierwsza koncentruje się na jednostce i jej cechach (wiedza, kompetencje, umiejętności, doświadczenie), druga — na danej organizacji jako całości ${ }^{9}$. Nietrudno zauważyć, że nasi rozmówcy, wskazując okoliczności sprzyjające sukcesowi w administracji publicznej, wpisują się w tę pierwszą perspektywę. Mówią przede wszystkim o konieczności posiadania merytorycznych kompetencji i szeroko rozumianych umiejętnościach komunikacyjnych oraz (już mniej często) o takich cechach, jak kreatywność, zaangażowanie czy rzetelność w ramach realizowanych zadań. Wskazania te z pewnością można uznać za desygnaty indywidualnego profesjonalizmu, a to, że występują w większości zgromadzonych narracji, świadczy, jak się wydaje, o przynajmniej częściowo podzielanym przekonaniu o procesie budowania tożsamości oraz kreowania tak właśnie rozumianej roli zawodowej.

Indywidualny profesjonalizm nie oznacza jednak profesjonalizmu instytucji jako całości, jest w najlepszym wypadku jego warunkiem koniecznym, ale zarazem niewystarczającym. Egzemplifikacją takiej sytuacji mogą być analizowane wywiady. Dyrektorzy departamentów mówią w nich w podobny sposób o indywidualnych cechach, mogących sprzyjać zawodowemu sukcesowi w administracji publicznej, i sporadycznie poruszają w tym kontekście kwestię sprzyjających jego kreowaniu cech swoich departamentów, ministerstw czy wreszcie administracji publicznej jako instytucji. Wszystkie wymieniane w tym wypadku instytucjonalne korelaty sukcesu odwoływały się do takich elementów, jak: przyjazne procedury [R. 39], sprawnie działajace zespoty [R. 31], jasny przekaz od kierownictwa [R. 23], otwarcie ministerstwa na zmiany [R. 15], przychylność podmiotów zewnętrznych [R. 1], i wreszcie sytuacje, w których departament ma jasno określony styl działania [...] jest wizja, która jest realizowana [R. 17]. Nikła obecność wskazań tego typu cech jako sprzyjających administracyjnym sukcesom nie wydaje się jednak wystarczającym powodem do formułowania konkluzji przedstawiających administrację publiczną na przykład jako nieprofesjonalne (i zapewne nieprzyjazne) środowisko organizacyjne, w którym wśród „zwykłych” urzędników funkcjonują samotni profesjonaliści. Naszym zdaniem sposób, w jaki dyrektorzy departamentów polskich ministerstw „konstruują rzeczywistość” ad-

${ }^{9} \mathrm{~W}$ tym wypadku przyjmuje się, że profesjonalizm organizacji jest pochodną profesjonalizmu jej członków. 
ministracyjnego sukcesu, należy raczej uznać za kolejny argument na rzecz tezy, że proces transformacji oznaczał - i oznacza nadal - konieczność ukształtowania postaw innych niż dotychczasowe, zbudowania nowych instytucji, wypracowania odmiennych sposobów regulacji i zarządzania itd.

Odpowiadający na pytanie o charakterystykę ustroju powstałego ostatnio w Polsce często posługują się kategorią „hybryda”, wskazując tym samym na fakt współwystępowania $\mathrm{w}$ systemie elementów starego i nowego porządku. Ekonomiści od początku transformacji toczą spory o to, ile powinno być rynku w gospodarce, i zgodnie twierdzą, że o kierunku jej ewolucji (niezależnie, jaką docelową postać przybierze) decydować będą dwa elementy: postawy ludzi oraz istniejące zasoby wiedzy i techniki w zakresie produkcji oraz zarządzania. Socjologowie rozkładają akcenty odmiennie. Stawiają pytania o zasoby oraz bariery tkwiące $z$ jednej strony w ludziach, a $z$ drugiej - w istniejącej kulturze $\mathrm{i}$ instytucjach istotnych dla przebiegu procesu transformacji i kształtu nowego systemu. To one składają się bowiem na kontekst, w którym dokonują się zmiany. W toku analizy badacze często odwołują się do tradycji socjologii rozumiejącej Maksa Webera i tych koncepcji, w których kładzie się nacisk na kwestie indywidualnych recept postępowania, znaczeń i interpretacji nadawanych instytucjom, procesom i zjawiskom społecznym, zakorzenionym $\mathrm{w}$ świecie osobistych, potocznych doświadczeń oraz w tradycji i w głębokich strukturach myślenia i działania (Skąpska 2002). Wreszcie badacze administracji publicznej zwracają uwagę, że zmiany systemu powodują, iż oczekiwania w stosunku do administracji oraz urzędników i, co $z$ tym się wiąże, oczekiwania odnoszące się do pełnionych przez nich ról organizacyjnych ulegają zmianie (Hensel, Glinka 2012; Wilkin 2013). Pojawienie się nowych oczekiwań nie oznacza jednak, że zastępują one stare, lecz raczej, że jedne i drugie współegzystują. Proces ten przebiega w sytuacji, w której „wiele osób jest niezadowolonych z jakości usług administracji i ma uzasadnione poczucie, że publiczne zasoby są marnotrawione. $Z$ kolei wielu urzędnikom przeszkadza świadomość, że ich praca jest źle oceniana przez współobywateli" (Płoskonka 2008, s. 171). Jednocześnie z części analiz empirycznych wyłania się raczej mało optymistyczny wizerunek własny urzędnika - nisko oceniającego prestiż swojego zawodu, raczej negatywnie postrzegającego system administracji, w którym pracuje, i obawiającego się ryzyka oraz konkurencji. Towarzyszą temu krytyczne uwagi kierowane pod adresem administracji publicznej (zwłaszcza rządowej), postrzeganej z kolei przez pryzmat braku koordynacji działań, niedostatecznej komunikacji, rutyny zastępującej innowacyjność czy nieefektywną politykę kadrową ${ }^{10}$.

Jednak taki wizerunek administracji wydaje się nadmiernie uproszczony. Nie tylko dlatego, że nie jest ona monolityczną instytucją o wyrazistej, spójnej aktywności, nakierowanej na realizację jednego, wspólnego interesu. Także

10 Zob. np. wyniki badań przedstawione w pracy Jakość rzadzenia w Polsce (Wilkin 2013, s. 415). 
dlatego, że w jej ramach — w konsekwencji procesu tranzycji — „stare”, wygenerowane przed 1989 rokiem wartości, praktyki, definicje ról i tożsamości zderzają się z nowymi. Trudno w chwili obecnej przewidywać, jaką kulturę organizacyjną ten proces wygeneruje, tym bardziej że przebiega on w złożonym i różnicującym się otoczeniu zewnętrznym. Zwraca na to uwagę Czesław Sikorski (2007, s. 86), pisząc o dwóch przeciwstawnych modelach kultur: profesjonalnej i populistycznej. Ta pierwsza sprzyja rozwojowi gospodarki rynkowej, druga może być dla niej hamulcem. W przypadku badanej grupy można sądzić, że pojawi się kultura mieszana, bliższa być może modelowi pragmatycznej administracji państwa organicznego niż modelowi tradycyjnej, racjonalistycznej biurokracji (Czaputowicz 2008). Podstawą do sformułowania takiej tezy są analizowane przez nas narracje.

Na narracje te składają się również refleksje zgromadzone w odpowiedzi na pytanie projekcyjne dotyczące rad, jakich dyrektorzy departamentów udzieliliby młodemu człowiekowi planującemu swoją zawodową przyszłość „w jednym z ministerstw" 11 . Wynika z nich, najogólniej rzecz biorąc, że przede wszystkim [...] taka osoba powinna mieć świadomość tego, jak ta praca wyglada $i$ jakie wiaża się z nia wyzwania [R. 19], ale jednocześnie dowiadujemy się także tego, jakie umiejętności i cechy są $\mathrm{w}$ niej obecnie szczególnie przydatne oraz po części tego, jak zmienia się polska administracja.

Jak więc - stosownie do doświadczeń naszych rozmówców — „ta praca wygląda"? Po pierwsze, trzeba zaakceptować to, że początki sa dość trudne. Pracujemy w zamkniętej, dużej strukturze [R. 11]. Po drugie, należy wziąć pod uwagę to, że rzeczywiście jakichś profitów finansowych praca w administracji nie daje [R. 10]. Po trzecie, jeżeli ktoś przychodzi do administracji nie tylko $z$ nastawieniem na jakieś kokosy finansowe, ale jakąs taka szybka kariere — no to się może szybko rozczarować. Tu trzeba $z$ pewna taka doza pokory i cierpliwości podchodzić [R. 10]. Po czwarte, należy włożyć między bajki to, że pracując $w$ administracji, nic się nie robi. To jest bzdura kompletna [R. 31] i bardzo szybko okazuje się, że w rzeczywistości pracy jest bardzo dużo [R. 34]. Po piąte, warto zdawać sobie sprawę z tego, że podjęcie pracy $w$ administracji to jest duża odpowiedzialność $i$ duży stres - niemniej jednak należy wziąć pod uwagę także to, że praca jest $w$ miarę stabilna [...] i bez naprawdę dużego przewinienia, dwukrotnej oceny negatywnej, można spokojnie pracować [R. 33]. Po szóste, osoba, która chce rozpocząć pracę $\mathrm{w}$ administracji, powinna wiedzieć o tym, że to jest stużba, że również będzie wymagała od niej dużego zaangażowania $w$ realizacje tych obowiązków [R. 34]. Innymi słowy — każda osoba, która podejmie decyzje o pracy $w$ administracji, powinna mieć świadomość, że to nie jest praca typu osiem godzin za biurkiem, spokojna, kawka w międzyczasie [...]. Tu sie pracuje na akord, jeżeli ktoś by tu przyszedt do pracy ze świadomościa, że sobie posiedzi

11 Kwestia ta była poruszana jako ostatnia w bloku pytań o sukces, a dyspozycja zawarta w scenariuszu wywiadu brzmiała następująco: „Jakiej rady udzieliłby Pan/i osobie planującej rozpoczęcie pracy i wiążącej swoją przyszłość zawodową z zatrudnieniem w jednym z ministerstw?”. 
— to sie zdziwi [R. 47]. Wreszcie, po siódme, zawodowa aktywność w administracji publicznej wymaga także dobrej organizacji wtasnego warsztatu pracy, no $i$ trzeba [...] podnosić swoje kwalifikacje systematycznie [R. 13].

Nietrudno zauważyć, że głęboko zakorzenione w opinii społecznej stereotypy dotyczące pracy $\mathrm{w}$ administracji publicznej są od powyższej charakterystyki dosyć odległe. Stres, odpowiedzialność, zaangażowanie, służba, wiele obowiązków, stała konieczność rozbudowywania wiedzy i kompetencji oraz cierpliwość w toku budowania kariery administracyjnej - to w tym przypadku kluczowe słowa używane przez naszych rozmówców. Ich refleksje na temat oczekiwanych od kandydata „na urzędnika” cech i talentów świadczą o tym, że w tak opisywanym środowisku pracy łatwiej jest odnaleźć się tym, którzy mają zadatki na profesjonalistów.

Otóż niemal wszyscy dyrektorzy — choć w nieco odmiennych stylistykach i kontekstach - mówili w tym wypadku o dążeniu do podnoszenia kwalifikacji merytorycznych oraz konieczności posiadania i pogłębiania wiedzy. Innymi słowy, podstawową cechą przyszłego urzędnika powinno oczywiście być zdobycie określonej wiedzy, która jest niezbędna $w$ działalności w każdym urzędzie [R. 17] oraz otwartość na nieustanne ksztatcenie [R. 13] i duże zainteresowanie tym, co się będzie robito $w$ tej pracy [R. 19]. Nie chodzi jednak wyłącznie o naturalną w takiej sytuacji ciekawość - raczej o postawę zaangażowania, aktywność, zapał, dociekliwość połaczona $z$ wiara $w$ siebie [R. 2]. Powinna jej też sprzyjać świadomość, że praca $\mathrm{w}$ administracji to jest jednak stużba, że za tymi decyzjami, które się tu podejmuje, jednak kryja się ludzie [R. 45]. Innymi słowy, jak również podkreślano, to nie sa czasy „urzędniczenia” [...] to sa czasy solidnej, uczciwej, często wypalajacej zawodowo pracy. I biorac się za tę pracę, trzeba gdzieś sobie wyryć raz na zawsze $w$ środku, że to jest rola stużebna [R. 32]. Adekwatną i wyczerpującą egzemplifikacją formułowanych oczekiwań, zarazem świadczącą o tym, że są one (lub bywają) obecne w praktyce funkcjonowania administracji, jest następująca wypowiedź: Chyba bym podkreślała to, czego ja wymagam od swoich pracowników - czyli na pewno inicjatywy, kreatywności, samodzielności, zaangażowania $w$ prace, szybkości działania, zdobywania wiedzy merytorycznej [R. 18].

Można powiedzieć - podobnie jak w przypadku charakterystyki pracy $\mathrm{w}$ administracji - że inicjatywa, kreatywność czy zaangażowanie, jako cechy wymagane od urzędników, są odległe od powszechnie podzielanych stereotypów. Można jednak także zaryzykować przypuszczenie, że rady udzielane przez dyrektorów departamentów wyobrażonym kandydatom stanowią świadectwo rejestrowanych przez nich zmian zachodzących w polskiej administracji. Nie sposób, powtórzmy, na podstawie tych wypowiedzi wyrokować o ostatecznym kształcie administracyjnych struktur oraz administracyjnej kultury. Jednak można wstępnie naszkicować kierunek potencjalnych zmian. Mam wielu znajomych $w$ administracji - mówi na przykład jeden $z$ dyrektorów — którzy tak na to patrza, $\dot{z}$ e to jest pewien system hierarchiczny, skostniaty: „Tu sie nic nie zrobi. Niezależnie, co robię i jak robię, to i tak nie ma znaczenia”. [...] Trochę może tak jest. 
Trochę można to tak postrzegać. Ja bym jednak doradzat taka wiare, że można to zmienić [R. 2]. Ostrożny optymizm, a raczej nadzieje dotyczące tego, że można „to”, czyli hierarchiczną i skostniałą strukturę polskiej administracji, zmienić, zarejestrowaliśmy kilkukrotnie. Narrację, w której ich wyrazem staje się już „głębokie poczucie" - tylko raz. Warto też dodać, że chodzi w tym wypadku bardziej o procesy definiowania pełnionej roli oraz misję niż administracyjne struktury. Wypowiedź ta brzmi tak: [...] jesteśmy od tego, żeby stużyć publicznie państwu i obywatelom tego panstwa. W mojej świadomości jest to najważniejsza zmiana mentalna wśród urzędników, która następuje, i myślę, ż już u bardzo wielu osób nastapita. Coś, co kiedyś wiązało się tylko $i$ wytacznie $z$ przekładaniem papierów, $z$ pokazywaniem, że sie rzaddzi - teraz się mocno zmienito. Przynajmniej ja mam takie głębokie poczucie [R. 34].

Można jednak dodać, biorąc pod uwagę kolejną refleksję, że zmiany urzędniczych postaw oraz mentalności nie obejmują (co skądinąd oczywiste) ogólu urzędników. W tym wypadku chodzi o dwie kwestie. Po pierwsze o to, żeby młody pracownik nie bat się takiego czarnego, pejoratywnego spojrzenia na urzędników, a po drugie o to, żeby się też nie bat zetknięcia $z$ takimi wieloletnimi pracownikami $i$ nie przejmowat od nich złych nawyków. One jednak gdzieś tam wciąz pokutuja i sa [obecne] [R. 15]. Na koniec zmiany, o których mówią nasi rozmówcy, świadczą także o malejącym wpływie jeszcze niedawno dobrze widocznego mechanizmu negatywnej selekcji do zawodu urzędnika. Okazuje się jednak, że $w$ tej chwili jest coraz lepiej $i$ praca $w$ administracji już nie jest takim wyjściem dla tych, których nie chca nigdzie indziej. Nam sie coraz lepsi ludzie trafiaja [...] sa osoby zaangażowane, sa osoby ambitne, inteligentne, bystre. I te osoby sa dostrzegane, zdecydowanie sa dostrzegane [R. 42].

W tym miejscu należy zwrócić uwagę na jeszcze jedną, wcześniej zapowiadaną kwestię. Otóż analizując uzyskane w trakcie wywiadów materiały, zwracałyśmy uwagę także na s po sób, w jaki przedstawiciele elit administracyjnych odczytują otaczającą ich rzeczywistość (rodzaj stosowanych narracji), wychodziłyśmy bowiem z założenia, że wywiera to wpływ na późniejsze zachowania jednostek, a tym samym ma konsekwencje społeczne. Szczególnie istotne były te autonarracje, które przybierały postać proaktywną lub defensywną ${ }^{12}$, ponieważ wynikało to ze sposobu, w jaki badani interpretowali własne problemy, dążenia i plany życiowe. Badacze zwracają uwagę, że to właśnie narracyjne przekazy kulturowe wpływają na umysłowość członków danej społeczności, wyznaczając obowiązujące w niej standardy (Drogosz, Trzebiński, Zięba 2005). Pełnią także ważną rolę w kształtowaniu poczucia tożsamości, zarówno indywidualnej, jak i społecznej. Tak rozumiana narracja pozwala zatem nie tylko na zrozumienie własnej osoby, ale pełni również ważną rolę jako przesłanka

\footnotetext{
12 Podstawowa różnica między jednym i drugim rodzajem autonarracji wiąże sie z tym, że $\mathrm{w}$ narracjach proaktywnych uwaga skupia się na intencjach oraz sposobach przekształcania ich w plany działań. $Z$ kolei narracje defensywne koncentrują się na pojawieniu się problemu, swoistym poczuciu zagrożenia, które uruchamia reakcję.
} 
później podejmowanych decyzji. Innymi słowy, można przypuszczać, że z perspektywy autonarracji proaktywnych życie jest postrzegane jako ciąg intencjonalnych działań podmiotu i jego partnerów, służących pokonywaniu powstających trudności (pojawia się poczucie sprawstwa). Natomiast z perspektywy autonarracji defensywnych jawi się ono jako ciąg zdarzeń obracających się wokół kłopotów i prób radzenia sobie z nimi. Oba typy autonarracji można także traktować jako sposoby długofalowej adaptacji do trwałych cech środowiska społecznego: „Z tego punktu widzenia, transformacja i rozwój w skali makrospołecznej - są na poziomie jednostkowych dążeń i preferencji — inspirowane i podtrzymywane przede wszystkim przez osoby interpretujące świat i działające w ramach proaktywnych autonarracji" (Drogosz, Trzebiński, Zięba 2005, s. 161).

Wypada przyznać, że wśród analizowanych przez nas narracji zdecydowaną większość stanowiły te, które mają charakter proaktywny. To prawda, że o sposobach definiowania i rozumienia sukcesu oraz jego korelatach rozmawiałyśmy z przedstawicielami elity administracyjnej, czyli tymi, którzy już go odnieśli. Jednak ich narracje przybierały postać proaktywną zwłaszcza wtedy, kiedy dotyczyły rad dla młodych ludzi rozważających podjęcie pracy w administracji. Nie mamy tutaj na myśli przedstawionych już wypowiedzi świadczących o toczących się w środowisku administracji zmianach. Przede wszystkim warte podkreślenia $\mathrm{w}$ tym wypadku wydaje się nam to, że zdecydowana większość respondentów była skłonna potencjalnych kandydatów zachęcać do podjęcia takiej decyzji. Zapewne dlatego, że - jak mówili — ci, którzy nie będą zniechęceni $w$ jakiś sposób, będa podejmowali bardziej świadomie pracę $w$ administracji [R. 39]. Dotyczące tej kwestii opinie trudno byłoby też uznać za pochwałę administracji. Świadczą one raczej o zgromadzonej dzięki praktycznym doświadczeniom wiedzy o wpisanych w nią dysfunkcjach i o tym, że postrzeganie „całego systemu" może być pozytywne, mimo że funkcjonowanie w jego ramach wymaga cierpliwości, wiadomo, bo to jest machina czasami skostniała [R. 2], i choć nikt nie daje gwarancji, że zawsze ten rozwój zawodowy będzie [...] więc jeśli ktoś liczy na to, że zrobi $w$ administracji szybka $i$ tatwa kariere, to powinien otworzyć wtasna dziatalność $i$ tam się realizować [R. 34]. Wreszcie również dlatego, że jest to na pewno droga do sukcesu [R. 30], choć nie jest on pewny ani oczywisty: To wymaga po prostu czasu, nabrania doświadczenia, pokory takiej właśnie $w$ zdobywaniu doświadczenia $w$ administracji [R. 34].

W zupełnie innym tonie toczyły się te narracje, które należy określić jako defensywne. Ich autorzy koncentrowali się przede wszystkim na problemach towarzyszących pracy $\mathrm{w}$ administracji i/lub odradzali wiązanie $\mathrm{z}$ nią przyszłości zawodowej. Dowiadujemy się więc, że: To jest bardzo trudna praca $i$ niewdzięczna dla tych młodych ludzi... często zderzaja się ich oczekiwania, [takie] o charakterze prawie marzeń z taka szara rzeczywistościa codziennej pracy tutaj [R. 36]. Być może dlatego rada udzielona przez innego $z$ dyrektorów, poprzedzona pytaniem o to, czy na pewno chcemy ją poznać, brzmi tak: Szczerze? żeby się głęboko [ta osoba] 
zastanowiła, czy odpowiada jej taki sposób pracy [...] to jest zupetnie coś innego niż prywatny biznes [...] nie ma systemu jasnych kryteriów [R. 26].

Dwóch z grona naszych rozmówców proponuje inne rozwiązanie. W gruncie rzeczy wpisana jest w nie taka strategia budowania kariery zawodowej, $\mathrm{w}$ której praca $\mathrm{w}$ administracji jest wyłącznie jednym $\mathrm{z}$ jej pierwszych etapów. W wersji lakonicznej ma ona postać następującą: Na pewno osobie rozpoczynajacej pracę bym powiedziat — tak, idź, spróbuj — ale nie siedź tam za długo [R. 6]. W wersji rozbudowanej zaś strategia proponowana osobie ubiegającej się o pracę w administracji centralnej jest taka: Żeby nie skupiata się tylko na niej, po pierwsze. A po drugie żeby ja wykorzystała po to, aby nabrać określonych umiejętności, określonej wiedzy i po jakimś czasie starata się z niej odejść. Takiej rady bym udzielit [R. 7].

Interesujące $\mathrm{w}$ przypadku analizy sposobów interpretowania administracyjnej rzeczywistości jest także to, że wśród zgromadzonych narracji — w tej części, której dotyczy prezentowany tekst - w zasadzie nie spotykamy narracji mieszanych. Ich ton i wymowa są albo ofensywne (najczęściej), albo defensywne, co świadczy, jak się wydaje, o wykształconych postawach i w miarę koherentnym postrzeganiu własnego środowiska zawodowego. Jedynie raz zarejestrowaliśmy wypowiedź wyrażoną w sposób, który należałoby chyba określić jako neutralny - ani proaktywny, ani defensywny. Jej autor, pytany o rady dla młodego kandydata „na urzędnika”, w pierwszym momencie mówi: Nie mam pojęcia, szczerze mówiąc. - I w chwilę potem dodaje — praca jak każda inna. $W$ pewnym momencie dostaje się więcej odpowiedzialności i robi się coś dla państwa [...]. Ale $w$ wielu miejscach, nie tylko $w$ administracji, robi się coś dla państwa [...]. A przy okazji oczywiście dla siebie, no bo się zarabia [R. 5].

$\mathrm{Z}$ przeprowadzonych wywiadów wyłania się, jak widać, raczej jednolity obraz badanego środowiska, w którym przeważają narracje o charakterze proaktywnym nad defensywnymi. Być może interpretując uzyskane wyniki należy odwoływać się bardziej do stosowanych racjonalizacji niż strategii działania? Badacze zwracają uwagę, że to właśnie narracyjne przekazy kulturowe wpływają na umysłowość członków danej społeczności, wyznaczając tym samym obowiązujące $\mathrm{w}$ niej standardy. Pełnią one również ważną rolę w kształtowaniu poczucia tożsamości, zarówno indywidualnej, jak i społecznej. Narracja jest zatem nie tylko sposobem na zrozumienie własnej osoby, ale pełni także ważną rolę jako przesłanka później podejmowanych decyzji.

Autorzy koncentrujący się na tej metodzie zwracają uwagę, że w przypadku autonarracji proaktywnych cechami jednostek, które szczególnie wpływają na ich aktywność, są inteligencja społeczna i inteligencja emocjonalna, zwiększające szanse powodzenia na zdobycie wsparcia społecznego, koniecznego przy podejmowaniu tego typu działań. Natomiast w przypadku autonarracji defensywnych ważną cechą modyfikującą skuteczność podejmowanych działań może być siła tak zwanej nadziei podstawowej, oznaczającej wiarę w świat sensowny i pozytywny, przychylny ludziom (Erikson 1997, 2002). Obie hipotezy wymagają jednak dalszej weryfikacji. 
Jaka jest zatem polska administracja państwowa? Czy — jak twierdzi Jerzy Wilkin (2013, s. 415): „Jakość polskiej administracji państwowej, ulega stopniowej poprawie, ale proces ten jest zbyt wolny, zwłaszcza w porównaniu z tym, co dzieje się w sektorze prywatnym"? Czy też, zgodnie $z$ wcześniej postawioną tezą, to immanentne cechy modelu biurokratycznego definiują role zawodowe i tożsamość polskich urzędników, a pojęcia takie jak kariera czy sukces nadal mają konotacje negatywne, mimo że budowa gospodarki rynkowej opiera się na indywidualnej przedsiębiorczości, w której pojęcie to zajmuje ważne miejsce?

Przystępując do badań zakładałyśmy, że idee i przekonania, a więc szeroko rozumiana wiedza teoretyczna i praktyczna reprezentantów administracji państwowej, oparta na podzielanych $z$ innymi przedstawicielami tej grupy ideach, przekonaniach i założeniach o rzeczywistości, określają jej misję w państwie, wizje normatywne „dobrego państwa”, „dobrej administracji”, „dobrego urzędnika czy „dobrego wyniku”, a także postrzeganie ograniczeń działania oraz sposobów ich pokonywania (Nalewajko, Post 2014). Tak rozumiana wspólnota myślenia powinna zatem sprzyjać podzielaniu tożsamości i osiąganiu konsensusu w zakresie preferowanych kierunków i sposobów działania, pokazując jednocześnie skalę homogeniczności lub heterogeniczności badanej grupy. Wychodziłyśmy także z założenia, że zarówno posiadane zasoby edukacyjno-zawodowe, jak i przyswojone $\mathrm{w}$ toku instytucjonalnej socjalizacji wzory myślenia i działania określają strategie administracji stosowane w jej wzajemnych relacjach, a także $w$ interakcjach $z$ innymi instytucjonalnymi partnerami, jak parlament czy partie polityczne.

Zebrane wypowiedzi pokazują, że tytułowy sukces ma dla badanych postać relacyjną: był on różnie postrzegany, w zależności od założonych celów, którymi mogą być zarówno realizowane przez poszczególne zespoły zadania, własny sukces zawodowy, jak i uzyskanie zewnętrznej pozytywnej oceny wykonywanej pracy.

W rozmowach pojawił się także kolejny, czwarty wymiar, mniej już oczywisty. Część naszych rozmówców mówiła, że o tym, czy coś można uznać za sukces lub nie, decyduje przyjęta wcześniej definicja. W wypowiedziach podkreślano także, że osiągnięcie sukcesu zależy przede wszystkim od umiejętności i cech indywidualnych urzędnika, takich jak wiedza, kompetencje oraz zdolności komunikacyjne. Wiążą się one z pojęciem profesjonalizacji, a nacisk kładziony na te właśnie umiejętności i cechy może wskazywać na toczący się proces budowania indywidualnego profesjonalizmu, który składałby się na nową tożsamość zawodową administracji publicznej. Zaobserwowanych przejawów indywidualnego profesjonalizmu nie powinniśmy jednak utożsamiać z profesjonalizacją instytucji. Albowiem cały dotychczasowy system zarządzenia państwem i gospodarką podlega przekształceniom. Pojawiają się rozwiąza- 
nia określane mianem „hybrydy”, oscylujące „pomiędzy” gospodarką rynkową a poprzednim systemem. Administracja publiczna nie jest tutaj wyjątkiem.

$Z$ prowadzonych analiz wyłania się niejednoznaczny obraz środowiska. $\mathrm{Z}$ jednej strony urzędnicy jawią się jako profesjonaliści, z drugiej — brakuje im „zakorzenienia” w istniejącej kulturze organizacyjnej, która sprzyjałaby kształtowaniu bardziej prorynkowych postaw. Podobne wnioski pojawiły się w przywoływanych już wcześniej badaniach: „Autodefinicja roli urzędnika jest sformułowana w sposób negatywny, w opozycji do przeszłości - nasi rozmówcy wiedzą, kim nie chcą być (peerelowskimi urzędnikami), ale nie mają wyrobionej wizji tego, kim chcieliby być [...] neoliberalny model państwa w gospodarce, promowany w ostatnich dwóch dekadach, nie zakorzenił się specjalnie głęboko w przekonaniach urzędników" (Hensel, Glinka 2012, s. 218-220).

Nadal zatem jesteśmy gdzieś „pomiędzy”, jeśli chodzi o budowę nowoczesnego państwa i jego administracji.

\section{BIBLIOGRAFIA}

Barber Bernard, 1963, Some Problems in the Sociology of the Professions, „Daedalus”, t. 92, s. 669-688. Bokszański Zbigniew, 1990, Pojęcie tożsamości jednostki a interakcjonizm symboliczny, w: Władysław Kwaśniewicz (red.), Orientacje teoretyczne we wspótczesnej socjologii, Uniwersytet Jagielloński, Kraków.

Czaputowicz Jacek, 2008, Stużba cywilna $w$ procesie integracji europejskiej, w: Jacek Czaputowicz (red), Administracja publiczna. Wyzwania $w$ dobie integracji europejskiej, Wydawnictwo Naukowe PWN, Warszawa.

Drogosz Marek, Trzebiński Jerzy, Zięba Mariusz, 2005, Styl autonarracji i poziom nadziei podstawowej a postawy spoleczne Polaków, w: Urszula Jakubowska, Krystyna Skarżyńska (red), Demokracja w Polsce. Doświadczanie zmian, Wydawnictwo SWPS Academica, Warszawa.

Erikson Erik, 1997, Dzieciństwo i spoteczeństwo, tłum. Przemysław Hejmej, Rebis, Poznań.

Erikson Erik, 2002, Dopetniony cykl życia, tłum. Aleksander Gomola, Rebis, Poznań.

Grzeszczyk Ewa, 2003, Sukces: amerykańskie wzory — polskie realia, Wydawnictwo IFiS PAN, Warszawa.

Harries-Jenkins Gwynn, 1970, Professionals in Organization, w: John A. Jackson (red), Professions and Professionalization, Cambridge University Press, Cambridge.

Hensel Przemysław, Glinka Beata, 2012, Urzędnicy i przedsiębiorcy: kulturowe bariery wspótpracy, Poltext, Warszawa.

Kafel Tomasz, 2013, Wymiary profesjonalizacji podmiotów ekonomii społecznej, „Biuletyn Ekonomii Społecznej", nr 2.

March James G., Olsen Johan P., 2005, Institutional Perspectives on Political Institution, doi: 10.1111/j.1468-0491 (pierwodruk: „Governance” 1996, t. 9, s. 247-264).

Nalewajko Ewa, Post Barbara, 2014, Dobre państwo i dobry urzędnik: krystalizacja wzorców normatywnych $w$ środowisku rzadowych elit administracyjnych, „Studia Polityczne”, nr 3.

Płoskonka Józef, 2008, Zarzadzanie przez rezultaty jako metoda wykonywania zadań $w$ administracji publicznej, w: Jacek Czaputowicz (red), Administracja publiczna. Wyzwania $w$ dobie integracji europejskiej, Wydawnictwo Naukowe PWN, Warszawa.

Sikorski Czesław, 2007, Drogi do sukcesu. Profesjonalizm kontra populistyczna kultura organizacyjna, Difin, Warszawa. 
Skąpska Grażyna, 2002, Buddenbrokowie czy piraci. Polscy przedsiębiorcy okresu głębokich przemian, Universitas, Kraków.

Trzebiński Jerzy, 2002, Narracja jako sposób rozumienia świata, Gdańskie Wydawnictwo Psychologiczne, Gdańsk.

Wilkin Jerzy, 2013, Kierunki reform systemu instytucjonalnego sprzyjających poprawie jakości rządzenia, w: Jerzy Wilkin (red), Jakość rzadzenia w Polsce. Jak ja badać, monitorować $i$ poprawiać?, Scholar, Warszawa.

\section{MODELS OF SUCCESS IN THE NARRATIVES \\ OF STATE ADMINISTRATIVE ELITES}

\section{Summary}

The article contains a qualitative analysis of statements by representatives of the Polish central administrative elite about the construction of their new roles and identity. It is assumed that one dimension of the new identity is the manner in which department directors (who were interviewed in 2013), define the concept of success, which seems 'by definition' to belong to the paradigm of a market economy. What does it thus mean for them and what are the consequences in terms of how they perceive their professional role? The author attempts to answer these questions.

\section{Key words/słowa kluczowe}

state administration / administracja państwowa; narratives / narracje; professionalism / profesjonalizm; success / sukces; market / rynek; identity / tożsamość 